\title{
Jurist-Diction
}

Volume 2 No. 6, November 2019

Histori artikel: Submit 1 Oktober 2019; Diterima 23 Oktober 2019; Diterbitkan online 1 November 2019.

\section{Penggunaan Trotoar Bagi Penyandang Disabilitas Ditinjau dari Undang-Undang No. 22 Tahun 2009 Tentang Lalu Lintas dan Angkutan Jalan}

\begin{abstract}
Hilmy Azy Nurmansyah
hilmy.azy.nurmansyah-2015@fh.unair.ac.id

Universitas Airlangga

Abstract

The sidewalk is supporting facilities on Highways Act No. 22 of year 2009 about traffic and road transport. The availability of the pavement must provide security and comfort to the pedestrian crossing. The subject of the pedestrians themselves are not reserved only for the normal community only. But also to all walks of life including to people with disability, such as tuna netra, wheelchair users and others. The discussion will be examined on in the writing of this related to the legal protection for the community disability traverses sidewalks in review of traffic and transport ACT the path. The purpose of this writing is to analyse whether the ACT on road transport and traffic already provides legal protection to the disabled, the disabiltas pass on the sidewalk because the sidewalk is one of the supporting facilities mentioned. The type of research used in this study is the Doctrinal Research. The results obtained from this research is the traffic laws and road transport has granted legal protection through the 121 article mentions that the pedestrian has the availability of sidewalks and other amenities in the way. This explains that the pedestrian has the right to pass on the highway without any interference from anywhere. Pedestrians here also includes persons with disability because of the disability, disabilities ACT based on a disability are also entitled to one of the accessibility and accessibility on the sidewalk. The Government itself also had a responsibility to keep the sidewalks in order to clean it from all acts that interfere with the walkers and also the application of sanctions for violators.
\end{abstract}

Keywords: Sidewalks; Pedestrians; Disability; Legal Protection.

\begin{abstract}
Abstrak
Trotoar adalah fasilitas pendukung jalan raya pada Undang-undang No. 22 tahun 2009 tentang lalu lintas dan angkutan jalan yang selanjutnya disebut UU lalu lintas dan angkutan jalan, ketersediaan trotoar harus memberikan keamanan dan kenyamanan kepada pejalan kaki yang melintas. Subjek pejalan kaki sendiri tidak hanya diperuntukkan bagi masyarakat normal saja. Tetapi juga kepada seluruh lapisan masyarakat termasuk kepada penyandang disabilitas, seperti tuna netra, pengguna kursi roda dan lain-lain. Pembahasan yang akan dikaji pada dalam penulisan ini terkait dengan perlindungan hukum bagi masyarakat disabilitas yang melintas di trotoar di tinjau dari UU lalu lintas dan angkutan jalan. Tujuan dari penulisan ini adalah untuk menganalisis apakah UU lalu lintas dan angkutan jalan sudah memberikan perlindungan hukum kepada penyandang disabiltas yang melintas di trotoar karena trotoar adalah salah satu fasilitas pendukung yang disebutkan. Tipe penelitian yang digunakan dalam penelitian ini adalah Doctrinal Research. Hasil yang didapat dari penelitian ini adalah Undang-undang lalu lintas dan angkutan jalan telah memberikan perlindungan hukum melalui Pasal 121 yang menyebutkan bahwa pejalan kaki berhak atas ketersediaan trotoar dan fasilitas lain dijalan raya. Hal ini menjelaskan bahwa pejalan kaki mempunyai hak penuh untuk melintas di jalan raya tanpa gangguan dari manapun. Pejalan kaki disini juga mencakup penyandang disabilitas karena berdasarkan UU penyandang disabilitas, seorang disabilitas juga berhak atas aksesibilitas dan salah satunya aksesibilitas di trotoar. Pemerintah sendiri juga mempunyai tanggung jawab untuk menjaga trotoar agar bersih dari segala tindakan yang mengganggu pejalan kaki dan juga penerapan sanksi bagi pelanggar.
\end{abstract}

Kata Kunci: Trotoar; Pejalan Kaki; Disabilitas; Perlindungan Hukum. 


\section{Pendahuluan}

Pengertian seorang penyandang disabilitas pada Undang-Undang No. 8 Tahun 2016 Tentang Penyandang Disabilitas adalah setiap orang yang mengalami keterbatasan fisik, intelektual, mental, dan/atau sensorik dalam jangka waktu lama yang dalam berinteraksi dengan lingkungan dapat mengalami hambatan dan kesulitan untuk berpartisipasi secara penuh dan efektif dengan warga negara lainnya berdasarkan kesamaan hak. Hambatan dan kesulitan seorang penyandang disabilitas juga dialami saat mengakses prasarana transportasi publik, salah satunya saat mengakses fasilitas trotoar. Hal ini disebabkan karena belum meratanya pembangunan fasilitas trotoar di berbagai daerah. Beberapa daerah yang ada trotoar terlihat belum berfungsi baik dan bentuk dari trotoar cukup membahayakan masyarakat disabilitas.Terutama masyarakat disabilitas yang menyandang tuna netra atau orang dengan gangguan penglihatan dan masyarakat yang menggunakan kursi roda. Kedua penyandang disabilitas tersebut kerap kali terdiskriminasi dengan belum optimalnya fasilitas trotoar, belum lagi masyarakat umum yang juga sering menggunakan fasilitas trotoar tidak sesuai peruntukkannya. Dengan adanya fenomena ini yang menjadi bahan evaluasi pemerintah setempat untuk memberikan perlindungan hukum kepada penyandang disabilitas, bagaimana harus menyediakan trotoar yang aman dan nyaman sesuai peraturan perundang-undangan. Selain itu juga memberikan berbagai upaya baik upaya preventif dan upaya represif terkait dalam suatu kebijakan terhadap seorang penyandang disabilitas yang terdiskriminasi.

Berdasarkan data Pusat Data Kementerian Sosial menyebutkan bahwa penyandang disabilitas terbanyak di Indonesia adalah seseorang dengan keterbatasan berjalan atau tidak dapat menggunakan bagian kaki, yaitu sebesar 300 ribu jiwa, ${ }^{1}$ hal ini sejalan bahwa seorang dengan keterbatasan fisik tidak bisa berjalan dan menggunakan kursi roda merupakan pihak yang banyak terdiskriminasi di trotoar karena belum optimalnya pembangunan trotoar. Dengan banyaknya jumlah

1 Badan Pusat dan Penelitian Kesejahteraan Sosial Pusat Data dan Informasi Kesejahteraan Sosial Jakarta 2012. www.perpustakaan.bappenas.go.id. dikunjungi 12 November [2018] 
penyandang disabilitas di Indonesia menjadi tantangan bagi pemerintah untuk menyediakan akses pelayanan publik yang optimal dan efisien. Termasuk juga akses penyediaan fasilitas trotoar yang memadai yang penulis bahas dalam penulisan ini.

Beberapa waktu ini di kota Surabaya terdapat pemberitaan bahwa fasilitas trotoar yang ada di Kota Surabaya masih sulit diakses oleh masyarakat disabilitas. Mereka menganggap bahwa beberapa benda yang dipasang seperti bollard atau patok pada trotoar tersebut membuat orang tersebut sulit untuk melintasinya. Selain itu salah satu masyarakat beranggapan bahwa bangunan guilding block atau jalur yang digunakan untuk penyandang tunanetra mempunyai warna yang tidak tepat karena berwarna hitam, padahal berdasar pembangunan guilding block internasional seharusnya mempunyai warna kuning karena untuk membantu yang low vision agar mudah melihat jalur tersebut. Dan benda-benda yang terpasang tersebut juga mungkin saja dapat mencelekai mereka.
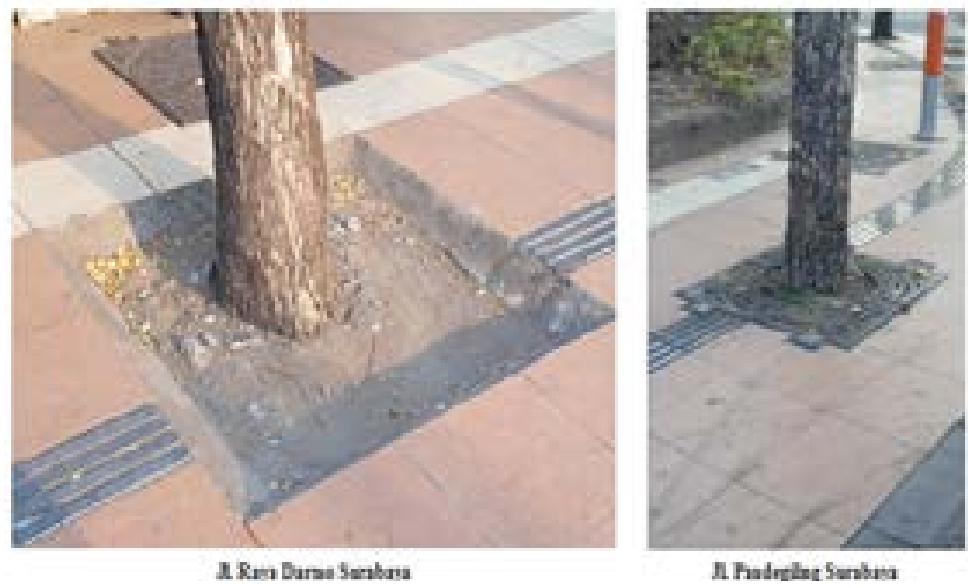

Penulis beberapa kali juga menjumpai bentuk trotoar di wilayah Surabaya yang dapat membahayakan penyandang disabilitas saat mereka melintasi trotoar. Seperti pada gambar diatas, bentuk trotoar yang berada di daerah Raya Darmo dan Pandegiling Surabaya tersebut bahwa guiding block pada trotoar tersebut putus dan terlihat terdapat pohon yang berdiri didepannya. Hal ini dapat membahayakan masyarakat tunanetra karena mereka tidak mengetahui jalur untuk mereka berjalan karena putusnya guiding block tersebut dan mereka juga dapat menabrak pohon yang berdiri tersebut. 


\section{Metode Penelitian}

Metode yang digunakan dalam penelitian ini adalah metode doctrinal research. Metode tersebut dilakukan dengan beberapa pendekatan-pendektan yatu pendekatan konseptual (Conceptual Approach) dan Pendekatan Undang-Undang (Statute Approach).

\section{Konsep Penggunaan dan Peruntukkan Trotoar}

Trotoar merupakan salah satu fasilitas pendukung bagi pejalan kaki dijalan raya berdasarkan UU Lalu Lintas dan Angkutan Jalan. Trotoar dalam Peraturan Menteri Pekerjaan Umum No 3/PRT/M/2014 Tentang Pedoman, Perencanaan, Penyediaan dan Pemanfaatan Prasarana dan Sarana Jaringan Pejalan Kaki di Kawasan Perkotaan. Trotoar adalah jalur pejalan kaki yang umumnya sejajar dengan sumbu jalan dan lebih tinggi dari permukaan perkerasan jalan untuk menjamin keselamatan pejalan kaki yang bersangkutan. Fungsi dari Trotoar sendiri adalah ruang yang diperuntukkan seluruhnya bagi pejalan kaki untuk menikmati fasilitas yang ada pada trotoar tersebut, aktifitas lain yang penggunaanya diluar untuk akses berjalan bagi pejalan kaki tidak boleh dilakukan seperti disalahgunakan untuk lahan parkir ataupun tempat berjualan. Dengan seiring dengan perkembangan jaman dan tingkat kepadatan penduduk yang semakin tinggi di berbagai wilayah, bentuk dari suatu trotoar pun juga semakin berkembang menyesuaikan dengan kebutuhan masyarakat. Masyarakat dari berbagai kalangan pun berhak mendapat fasilitas trotoar yang aman dan nyaman. Hal ini yang terus dikembangkan oleh pemerintah sebagai kewajiban untuk memberikan pelayanan yang maksimal bagi seluruh kalangan masyarakat.

Menurut penulis, sistem transportasi dan prasarana transportasi adalah hal yang saling ketergantungan apabila prasarana baik maka transportasi akan lancar, namun apabila prasarana buruk maka transportasi akan buruk. Misalnya saja apabila prasarana seperti trotoar mempunyai fungsi yang optimal dan efektif, maka seseorang akan tergerak atau mempunyai inisiatif untuk berjalan kaki dan akhirnya menggunakan fasilitas transportasi umum. Apabila masyarakat banyak menggukan 
fasilitas transportasi umum, maka angka kemacetan akan berkurang, dan apabila kemacetan berkurang maka mobilitas sistem transprtasi yang bermanfaat dibidang ekonomi, politik dan sosial akan lebih cepat tersalurkan. Apabila transportasi buruk maka menimbulkan kemacetan, banyak menyebabkan pengguna jalan melakukan pelangaran lalu lintas dan tidak tertib. Tradisi ketidaktertiban yang mewarnai perilaku kebanyakan pengemudi dijalan tidak hanya merugikan pengguna jalan lain, tetapi juga kondisi kemacetan di area jalanan tersebut. ${ }^{2}$

\section{Pembentukan Sarana dan Prasarana Untuk Pejalan Kaki dan Pembentukan Jalur Trotoar}

Pejalan kaki berhak untuk mendapatkan fasilitas yang aman dan nyaman dalam melintas di ruang lalu lintas jalan. Ruang lalu lintas jalan berdasarkan UU Lalu Lintas dan Angkutan Jalan adalah prasarana yang diperuntukkan bagi gerak pindah kendaraan, orang, dan/atau barang yang berupa jalan dan fasilitas pendukung. Berdasarkan Peraturan Menteri Pekerjaan Umum No. 03/PRT/M/2014 Tentang Pedoman, Perencanaan, Penyediaan dan Pemanfaatan Prasarana dan Sarana Jaringan Pejalan Kaki di Kawasan Perkotaan. Pengertian Prasarana Jaringan Pejalan Kaki adalah fasilitas utama berupa jaringan yang disediakan untuk pejalan kaki dan yang dimaksud sarana jaringan pejalan kaki adalah fasilitas pendukung pada jaringan pejalan kaki yang dapat berupa bangunan pelengkap petunjuk informasi maupun alat penunjang lainnya yang disediakan untuk meningkatkan kenyamanan dan keamanan pejalan kaki. Penyediaan dan pemanfaatan prasarana dan sarana jaringan pejalan kaki selain bermanfaat berjalan dari suatu tempat ke tempat yang lain juga bermanfaat untuk: ${ }^{3}$

a. Mendukung upaya revitalisasi kawasan perkotaan;

b. Merangsang berbagai kegiatan ekonomi untuk mendukung perkembangan kawasan bisnis yang menarik;

c. Menghadirkan suasana dan lingkungan yang khas, unik, dan dinamis;

2 Farouk Muhammad, Praktik Penegakan Hukum Bidang Lalu Lintas (Balai Pustaka 1999).[40].

3 Pedoman, Perencanaan, Penyediaan dan Pemanfaatan Prasarana dan Sarana Pejalan Kaki di Kawasan Perkotaan (diatur didalam Peraturan Menteri Pekerjaan Umum No.03/PRT/M/2014). 
d. Menumbuhkan kegiatan yang positif sehingga mengurangi kerawanan lingkungan termasuk kriminalitas;

e. Menurunkan pencemaran udara dan suara;

f. Melestarikan kawasan dan bangunan bersejarah;

g. Mengendalikan tingkat pelayanan jalan; dan

h. Mengurangi kemacetan lalu lintas.

Faktor-faktor diatas ini adalah keuntungan apabila sarana serta prasarana jaringan untuk pejalan kaki dibuat dengan optimal serta berlangsung terus menerus secara optimal dan efisien. Sudut atau ruas-ruas daerah yang sebelumnya tidak terurus atau terbengkalai dapat direvitalisasi kembali menjadi wilayah yang mempunyai nilai positif serta berdampak baik bagi lingkungan sekitarnya seperti ruas jalan yang sebelumnya rusak lalu dibangun trotoar disertai tanaman-tanaman, akan menambah mempercantik wilayah tersebut serta mengurangi hal-hal negative seperti pencemaan lingkungan, polusi dan lai-lain.

\section{Konsep Trotoar Untuk Penyandang Disabilitas}

Berdasarkan Peraturan Menteri Perhubungan No. PM 98 Tahun 2017 Tentang Penyediaan Aksesibilitas Pada Pelayanan Jasa Transportasi Publik Bagi Pengguna Jasa Berkebutuhan Khusus, Aksesibilitas bagi pengguna jasa berkebutuhan khusus pada sarana transportasi paling sedikit harus meliputi:

a. Alat bantu untuk naik turun dari dan ke sarana transportasi;

b. Pintu yang aman dan mudah diakses;

c. Informasi audio/visual tentang perjalanan yang mudah diakses;

d. Tanda/petunjuk khusus pada area pelayanan di sarana transportasi yang mudah di akses;

e. Tempat duduk prioritas dan toilet yang mudah diakses;

f. penyediaan fasilitas bantu yang mudah diakses, aman dan nyaman.

Pokok-pokok diatas seharusnya sudah harus tersedia demi terpenuhinya hak seorang penyandang disabilitas, hal-hal diatas menurut penulis bukanlah sesuatu yang sulit untuk diwujudkan jika melihat ketersediaan aksesibilitas dijaman sekarang ini, keenam hal tersebut akan membantu mewujudkan terpenuhinya hak seorang penyandang disabilitas untuk aksesibilitas dibidang transportasi. Selain itu ada peraturan-peraturan lain yang juga memberikan ketentuan bagaimana seharusnya bentuk trotoar yang layak bagi penyandang disabilitas, yang mana trotoar dibentuk 
sedemikan rupa agar memberkan rasa aman dan nyaman bagi penggunanya.

Ketentuan bagi penyandang disabilitas berdasarkan Peraturan Menteri Pekerjaan Umum No. 03/PRT/M/2014 Tentang Pedoman, Perencanaan, Penyediaan dan Pemanfaatan Prasarana dan Sarana Pejalan Kaki di Kawasan Perkotaan yang disediakan bagi pejalan kaki berkebutuhan khusus dalam peraturan tersebut yaitu: 1). Ramp diletakkan disetiap persimpangan, prasarana ruang pejalan kaki yang memasuki pintu keluar masuk bangunan atau kaveling dan titik-titik penyeberangan

2). Jalur difabel diletakkan disepanjang sarana dan prasarana jaringan pejalan kaki; dan

3). Pemandu atau tanda - tanda bagi pejalan kaki yang antara lain meliputi tandatanda pejalan kaki yang dapat diakses, sinyal suara yang dapat didengar, pesanpesan verbal, informasi lewat getaran dan tekstur ubin sebagai pengarah dan peringatan

\section{JALUR PEMANDU :}

a. Tekstur ubin pengarah bermotif garis-garis menunjukkan arah perjalanan.

b. Tekstur ubin peringatan (bulat) memberi peringatan terhadap adanya perubahan situasi di sekitarnya

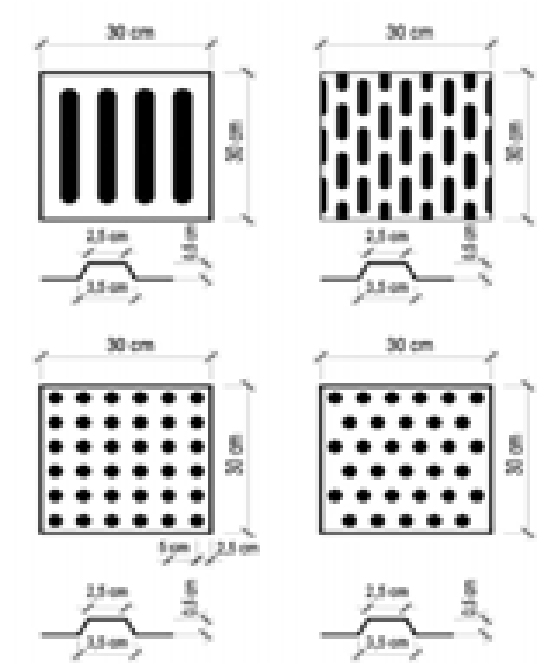

Daerah-daerah yang harus menggunakan ubin tekstur pemandu (guiding blocks):

1. Di depan jalur lalu-lintas kendaraan;

2. Di depan pintu masuk/keluar dari dan ke tangga atau fasilitas persilangan dengan perbedaan ketinggian lantai; 
3. Di pintu masuk/keluar pada terminal transportasi umum atau area penumpang; 4. Pada pedestrian yang menghubungkan antara jalan dan bangunan; dan

5. Pada pemandu arah dari fasilitas umum ke stasiun transportasi umum terdekat. Memang cukup sulit merealisasikan trotoar yang layak bagi masyarakat, kerap ada tantangan dan hambatan yang dihadapi dalam kaitannya dengan pengelolaan jaringan prasarana transportasi, aspek yang kerap menjadi permasalahan meliputi aspek kelembagaan dan peraturan, aspek sumber daya manusia, aspek kemajuan teknologi, aspek pendanaan investasi, aspek kapasitas infrastruktur dan aspek operasi pemeliharaan. ${ }^{4}$ Namun semua aspek tersebut akan teratasi apabila pemerintah dapat bersinergi melibatkan banyak pihak termasuk beberapa stakeholder yang terkait untuk bekerjasama dan juga sosialisasi serta diskusi bersama masyarakat dalam penyelesaian masalah dan solusi yang dicari. Kenyamanan suatu ruang akan berkurang apabila fasilitas prasarana yang tidak tertata dengan baik, untuk itu perlu penataan ruang yang fungsionalitas demi terciptanya kelancaran aktifitas, baik sebagai ruang transisi maupun ruang beraktifitas. ${ }^{5}$

\section{Perlindungan Hukum Bagi Masyarakat Disabilitas Yang Menggunakan Fasilitas Trotoar}

Subjek hukum selaku pemilik hak dan pelaksana kewajiban, dapat melakukan perbuatan hukum yang menimbulkan akibat hukum berdasarkan kemampuan atau kewenangan yang dimiliki subjek hukum. Dalam kehidupan di dalam masyarakat, sering terjadi hubungan-hubungan hukum yang timbul sebagai akibat adanya perbuatan hukum dari subjek hukum itu, yakni interaksi antara subjek hukum satu dengan subjek hukum lain yang memiliki relevansi hukum atau menimbulkan akibat-akibat hukum. agar hubungan hukum antara subjek hukum itu berjalan secara harmonis, seimbang, dan adil atau dalam arti lain setiap objek hukum mendapatkan apa yang menjadi haknya setelah ia melaksanakan kewajiban yang diberikan kepadanya, maka hukum ada sebagai aturan main dalam mengatur hubungan hukum tersebut.

4 Sakti Adji Adisasmita,Transportasi Komperehensif dan Multimoda (Graha Ilmu 2014).[19].

5 Rina Saraswati, 'Kenyamanan Pejalan Kaki Terhadap Pemanfaatan Trotoar Di Jalan Brigjen Katamso Medan' (2017) 3 Jurnal Education Building.[10]. 
Hukum diciptakan sebagai sarana atau instrumen untuk mengatur hak-hak dan kewajiban-kewajiban subjek hukum. Selain itu hukum berfungsi sebagai instrumen perlindungan bagi subjek hukum. Perlindungan hukum diberikan kepada pihak yang hak-haknya tidak terpenuhi atau dilanggar padahal dia berhak secara penuh untuk memperoleh hak tersebut. Pelanggaran hukum terjadi ketika subjek hukum tertentu tidak menjalankan kewajiban yang seharusnya dijalankan atau karena melanggar hak-hak subjek hukum lain. Subjek hukum yang dilanggar hakhaknya harus mendapatkan perlindungan hukum.

Pada kasus ini subjek hukum adalah seorang penyandang disabilitas, yaitu sekelompok minoritas yang ada dalam kehidupan masyarakat yang sering kali terdiskriminasi dalam pemenuhan hak-haknya, hak melintas di trotoar dengan aman dan nyaman pun belum sepenuhnya dirasakan oleh penyandang disabilitas. Menjadi wewenang bagi pemerintah untuk memberikan perlindungan hukum bagi masyarakat disabilitas, lalu bagaimana dengan pelanggaran yang dilakukan oleh oknum pelanggar lalu lintas dalam hal ini oknum yang melakukan pelanggaran diatas totoar. Dalam berbagai kasus yang sudah dijelaskan pada Bab I tulisan ini, oknum pelanggar adalah pihak yang menggunakan trotoar sesuai peruntukkannya yaitu seperti pedagang yang menjajakan dagangannya diatas trotoar, lalu orangorang yang melintas di atas trotoar menggunakan kendaraan bahkan menggunakan trotoar sebagai tempat parkir.

Menurut penulis, bila melihat fenomena seorang penyandang disabilitas yang dirugikan saat melintas diatas trotoar yang kerugiannya adalah tidak bisa melintas secara aman dan nyaman dikarenakan berkurangnya ruang di trotoar atau bahkan sama sekali kehilangan ruang untuk melintas oleh pihak yang melanggar tersebut, ada pelanggaran norma perdata dalam kasus ini, ada perbuatan melanggar hukum yang dilakukan oleh pelanggar.

Mengacu pada pasal 1365 BW “tiap perbuatan melanggar hukum, yang membawa kerugian kepada orang lain, mewajibkan orang yang karena salahnya menerbitkan kerugian itu, mengganti kerugian tersebut".

Dari Pasal 1365 BW bila ditelaah unsur-unsur PMH sebagai berikut : 
1. Ada perbuatan melanggar hukum;

2. Adanya hubungan kausalitas antara para pihak yang menimbulkan kerugian salah satu pihak;

3. Pemberian ganti rugi.

Kualifikasi perbuatan melanggar hukum ada beberapa jenis :

1. Bertentangan dengan kewajiban si pelaku hukum, dalam hal ini ada kewajiban bagi masyarakat untuk menggunakan trotoar sesuai peruntukannya.

2. Bertentangan dengan hak subjektif orang lain, dalam kasus ini pejalan kaki termasuk penyandang disabilitas kehilangan haknya dalam melintas di trotoar;

3. Bertentangan dengan kesusilaan;

4. Bertentangan dengan kepatutan, ketelitian dan kehati-hatian, pada kasus ini pelanggar melakukan pelanggaran pada UU lalu lintas dan angkutan jalan dan atas perbuatannya tersebut dapat menimbulkan kerugian bagi orang lain.

Bila dihubungkan pasal tersebut dengan kasus ini yaitu pelanggar yang mengambil hak pejalan kaki untuk melintas di trotoar demi kepentingan pribadi dan atas perbuatannya tersebut menimbulkan kerugian bagi pejalan kaki, pejalan kaki berhak untuk mengajukan tanggung gugat kepada pelanggar apabila ia merasa dirampas haknya dan mengalami kerugian materiil. Pejalan kaki berhak mengajukan gugatan PMH kepada pelanggar apabila diperlukan dan kejadian tersebut terjadi secara berulang-ulang. Dalan Pasal 1367 BW "seseorang tidak saja bertanggung jawab untuk kerugian yang disebabkan perbuatannya sendiri, tetapi juga untu kerugian yang disebabkan perbuatan orang-orang yang menjadi tanggungjawabnya atau disebabkan oleh barang-barang yang ada dibawah pengawasannya" Pasal tersebut bila dikaitkan dalam kasus ini seseorang yang melakukan pelanggaran diatas trotoar dan arena perbuatannya tersebut menimbulkan kerugian bagi pejalan kaki harus bertanggungjawab atas perilakunya. Melihat kondisi tersebut pemerintah pun harus turun tangan dalam menyelesaikan kasus ini yaitu dengan membentuk suatu peraturan yang melindungi hak pejalan kaki yang sekarang di implementasikan dalam UU Lalu Lintas dan Angkutan Jalan. 


\section{Persamaan Hak Penyandang Disabiltas}

Seorang penyandang disabilitas mempunyai hak dan kewajiban yang sama dengan masyarakat biasa lainnya, penyandang disabilitas juga memiliki kesempatan untuk turut serta berpartisipasi dalam rangka pembangunan nasional, hal ini dijelaskan pada Pasal 1 angka 2 UU Penyandang Disabilitas bahwa ada istilah kesamaan kesempatan.

Pasal 1 angka 2 UU Penyandang Disabilitas :

'Kesamaan kesempatan adalah keadaan yang memberikan peluang dan/ atau menyediakan akses kepada penyandang disabilitas untuk menyalurkan potensi dalam segala aspek penyelenggaraan negara dan masyarakat".

Adanya kesempatan turut serta bagi penyandang disabilitas dalam pembangunan nasional merupakan wujud upaya penghormatan, pemajuan dan pemenuhan hak penyandang disabilitas untuk mengembangkan diri serta mendayagunakan seluruh kemampuan serta bakat dan minat yang dimiliki penyandang disabilitas agar tersalurkan dan berkontribusi secara optimal.

Jika ditarik kembali keawal maka persamaan hak bagi penyandang disabiltas merupakan implementasi dari adanya konsep Hak Asasi Manusia. Pengertian Hak Asasi Manusia pada Undang-undang No. 39 Tahun 1999 tentang Hak Asasi Manusia. Pasal 1 angka 1 Undang-undang No. 39 Tahun 1999 Tentang hak Asasi Manusia:

'HAM adalah seperangkat hak yang melekat dan pada hakikat dan keberadaan manusia sebagai makluk Tuhan Yang Maha Esa dan merupakan anugerahNYA, yang wajib dihormati, dijunjung tinggi dan dilindungi oleh negara hukum, pemerintah dan setiap orang demi kehormatan serta perlindungan harkat dan martabat manusia".

Bila dihubungkan antara kedua Pasal diatas maka setiap orang berhak untuk dijunjung tinggi hak-haknya dan hak tersebut harus dilindungi dan dihormati oleh setiap manusia termasuk hak bagi penyandang disabilitas. Sumber hak berasal dari pemikiran moral manusia. Kegunaan dari hak asasi manusia yaitu melindungi harkat serta martabat manusia. Dari keterangan diatas maka dapat dilihat hakikat dari hak asasi manusia sendiri yaitu: ${ }^{6}$

6 Willy Putra, 'Pelaksanaan Perlindungan Hukum Terhadap Persamaan Hak Bagi Kelompok Penyandang Disabilitas Dalam Angkutan Penerbangan' (2018) 1 Jurnal Hukum Adigama.[9]. 
- Hak asasi manusia tidak dapat diberikan, dibeli, dan diwarisi, hak asasi manusia murni bagian dari manusia secara otomatis dan mutlak sejak lahir;

- Hak asasi manusia berlaku bagi semua orang tidak memandang jenis kelamin, ras,agama,etnis,pandangan politik atau asal-usul sosial dan bangsa;

- Hak asasi manusia tidak dapat dilanggar oleh siapapun.

Tidak ada yang bisa membatasi atau melanggar hak orang lain. Sehingga tidak ada seorangpun yang dapat melakukan pengurangan maupun perampasan terhadap hak asasi seseorang. Apabila ada pembatasan sebagaimana yang terdapat dalam Pasal 28 J UUD NRI 1945 hanya boleh dilakukan dengan Undang-undang. Hak Penyandang Disabilitas adalah bagian dari HAM. Penyandang disabilitas sekalipun tidak disebut secara tegas dalam UUD NRI tahun 1945, namun perlindungan terhadap subjeknya tetap harus diatur. Sebagaimanan prinsip dalam HAM yang universal, non diskriminasi, tidak dapat dipungkiri, tidak dapat dibagi dan tidak dapat dikurangi.

\section{Hak Penyandang Disabilitas dalam Hukum Nasional}

Pemenuhan terhadap penyandang disabilitas menjadi tanggungjawab pemerintah dalam hal ini sebagaimana yang tertuang dalam Pasal 28 I UUD NRI 1945. Dalam Pasal 34 ayat (2) UUD NRI 1945 ditentukan bahwa negara mengembangkan sistem jaminan sosial bagi seluruh rakyat dan memberdayakan masyarakat yang lemah dan tidak mampu sesuai dengan martabat kemanusiaan. Indonesia juga telah memiliki UU Penyandang Disabilitas dari Undang-Undang No. 4 tahun 1997 tentang Penyandang cacat menjadi Undang-Undang No. 8 Tahun 2016 tentang Penyandang Disabilitas. Selain pada substansinya, perubahan terdapat pada pengunaan kata "disabilitas" sebagai pengganti kata "cacat". Perubahan kata cacat menjadi disabilitas bukan tanpa alasan, istilah "cacat" memiliki konotasi yang negatif, peyoratif, dan tidak bersahabat bagi mereka yang memiliki kelainan. ${ }^{7}$ Persepsi ini dianggap sebagai kelompok yang yang serba kekurangan, tidak mampu

\footnotetext{
7 Akhmad Soleh, Aksesibilitas Penyandang Disabilitas terhadap Peguruan Tinggi : Studi kasus Empat Perguruan Tinggi di Yogyakarta (LKIS 2016).[17].
} 
dan perlu dikasihani, hal tersebut jelas tidak sesuai dengan nilai kemanusiaan dan kesetaraan yang melindungi dan menjamin kesamaan hak asasi sebagai seorang manusia. Dalam pasal 2 UU Penyandang Disabilitas. Penyandang Disabilitas berasaskan penghormatan terhadap martabat, otonomi individu, tanpa diskriminasi, partisipasi penuh, keragaman manusia dan kemanusiaan, kesamaan kesempatan, kesetaraan, aksesibilitas, kapasitas yang terus berkembang dan identitas anak, inklusif, dan perlakuan khusus dan perlindungan lebih.

\section{Hak Penyandang Disabilitas dalam Hukum Internasional}

Pada tanggal 13 Desember 2006 Majelis Umum Perserikatan Bangsa Bangsa telah mengeluarkan Resolusi Nomor A/61/106 mengenai Convention on the Rights of Persons with Disabilities (Konvensi tentang Hak-Hak Penyandang Disabilitas). Isi dalam resolusi tersebut menjelaskan tentang hak-hak penyandang disabilitas dan menyatakan akan mengambil langkah-langkah untuk menjamin pelaksanaan konvensi ini. Pemerintah Indonesia telah meratifikasi Convention on the Rights of Persons with Disabilities (Konvensi mengenai Hak-Hak Penyandang Disabilitas) pada tanggal 30 Maret 2007 di New York, Amerika Serikat. ${ }^{8}$ Hak-hak penyandang disabilitas dalam (Convention on The Rights of Persons with Disabilities) Konvensi Hak-Hak Penyandang Disabilitas yang juga telah diratifikasi oleh Undang-undang No. 19 Tahun 2011 disebutkan bahwa setiap penyandang disabilitas harus bebas dari penyiksaan atau perlakuan yang kejam, tidak manusiawi, merendahkan martabat manusia, bebas dari eksploitasi, kekerasan dan perlakuan semena-mena, serta memiliki hak untuk mendapatkan penghormatan atas integritas mental dan fisiknya berdasarkan kesamaan dengan orang lain. Terdapat delapan prinsip yang menjadi pedoman negara peserta dalam pemenuhan hak penyandang disabilitas dalam Convention on The Rights of Persons with Disabilities:

1. Penghormatan atas martabat yang melekat, otoritas individual termasuk untuk membuat pilihan sendiri dan kemandirian setiap orang;

8 Sandro Gatra,'Konvensi Hak Penyandang Disabilitas Diratifikasi'(2018) www.nasional. kompas.com, diakses pada 12 November 2018. 
2. Non diskriminasi;

3. Partisipasi penuh dan efektif, serta keterlibatan dalam masyarakat;

4. Penghormatan atas perbedaan dan penerimaan bahwa disabilitas adalah bagian dari keragaman manusia dan kemanusiaan;

5. Kesetaraan kesempatan;

6. Aksesibilitas;

7. Kesetaraan antara laki-laki dan perempuan;

8. Penghormatan atas perkembangan kapasitas penyandang disabilitas anak dan penghormatan atas hak penyandang disabilitas anak untuk mempertahankan identitas mereka.

Hak atas aksesibilitas penyandang disabilitas pun sudah diatur dalam konvensi menunjukkan bahwa beberapa negara pun menyadari bahwa seorang penyandang disabilitas merupakan subjek yang juga harus terpenuhi hak-haknya. Indonesia sebagai salah satu negara yang meratifikasi konvensi tersebut pun sudah melakukan upaya yang tepat, hanya implementasinya saja yang perlu dioptimalkan. Pemerintah mempunyai kewajiban dan tanggung jawab untuk menghormati, melindungi, dan memajukan hak asasi manusia, dalam hal ini adalah hak bagi penyandang disabilitas. Kewajiban pemerintah tidak hanya berhenti pada kebijakan formulatif saja (pembuatan peraturan perundang-undangan), namun juga pada kebijakan aplikatif, ${ }^{9}$ dimana peraturan yang sudah dibuat dan disahkan harus dilaksanakan secara optimal dan ada dampak dan implementasi yang positif dari adanya peraturan tersebut. Pada penyandang disabilitas harus dibekali dengan pendidikan dan keterampilan sehingga ketika mereka dewasa menjadi pribadi yang mandiri dan mampu beradaptasi dengan lingkungan. ${ }^{10}$

Perlindungan hukum terhadap penyandang disabilitas yang melintas di Trotoar dilihat dari UU Lalu Lintas dan Angkutan Jalan terdapat pada Pasal 131:

(1) Pejalan Kaki berhak atas ketersediaan fasilitas pendukung berupa trotoar, tempat penyeberangan, dan fasilitas lain

(2) Pejalan Kaki berhak mendapat prioritas pada saat menyeberang jalan ditempat penyeberangan.

9 Muladi, Hak Asasi Manusia : Hakekat, Konsep, dan Implikasinya dalam Perspektif Hukum dan Masyarakat (Refika Aditama 2005).[262].

${ }^{10}$ Aprilina Prawesti 'Hak Penyandang Disabilitas Dalam Perspektif HAM Internasional dan HAM Nasional'(2017) 2 Jurnal Era Hukum.[168] 
Subyek seorang pejalan kaki pada pasal diatas juga berlaku bagi seorang penyandang disabilitas. Karena seorang penyandang disabilitas juga mempunyai hak yang sama yaitu hak atas aksesibilitas menikmati sarana dan prasarana transportasi secara aman dan nyaman dan hal tersebut sudah disebutkan pada UU Penyandang Disabilitas Jadi pejalan kaki pada pasal tersebut berlaku bagi seluruh elemen masyarakat baik masyarakat normal maupun disabilitas. Penyediaan trotoar yang layak berdasar Pasal 131 UU lalu lintas dan angkutan jalan merupakan upaya preventif dari pemerintah untuk memberikan perlindungan hukum bagi penyandang disabilitas. Trotoar yang disediakan harus pula memenuhi karakteristik suatu trotoar berdasar peraturan perundang-undangan.

\section{Pertanggungjawaban Terhadap Pejalan Kaki dan Sanksi bagi Pelanggar}

Suatu trotoar apabila sudah tersedia maka tidak boleh dibiarkan begitu saja, seluruh elemen baik masyarakat dan pemerintah harus memelihara fasilitas umum tersebut. Trotoar yang rusak dapat menyebabkan terjadinya suatu kecelakaan, lalu bagaimana tanggung jawabnya. Kerap kali masyarakat merasa dirugikan atas rusaknya suatu trotoar. Pada Pasal 238 UU Lalu Lintas dan Angkutan Jalan:

(1) Pemerintah menyediakan dan/atau memperbaiki pengaturan sarana dan prasarana lalu lintas yang menjadi penyebab kecelakaaan.

(2) Pemerintah menyediakan alokasi dana untuk pencegahan dan penanganan kecelakaan lalu lintas.

Pada Pasal tersebut menjelaskan ada tanggung jawab pemerintah apabila terjadi suatu kecelakaan sarana dan prasana lalu lintas, seperti trotoar. Tetapi kita sebagai masyarakat tidak boleh hanya terpaku pada ketentuan tersebut, masyarakat wajib tetap memelihara fasilitas umum untuk menghindari terjadinya suatu kecelakaan. Tetapi bagaimana apabila kecelakaan terjadi akibat ulah oknum yang menyalahgunakan fungsi trotoar seperti menggunakan motor diatas trotoar lalu mengganggu hak pejalan kaki. Menurut Undang-Undang No. 22 Tahun 2009 Tentang Lalu Lintas dan Angkutan Jalan :

Pasal 274 ayat (1) UU Lalu Lintas dan Angkutan Jalan : 
"setiap orang yang melakukan perbuatan yang mengakibatkan kerusakan dan/ atau gangguan fungsi jalan sebagaimana dimaksud dalam Pasal 28 ayat (1) dipidana dengan pidana penjara paling lama 1 (satu) tahun atau denda paling banyak Rp.24.000.000,00 (dua puluh empat juta rupiah)".

Pasal 275 ayat (1) UU Lalu Lintas dan Angkutan Jalan :

"setiap orang yang melakukan perbuatan yang mengakibatkan gangguan pada fungsi rambu lalu lintas, marka jalan, alat pemberi isyarat, fasilitas pejalan kaki dan alat pengaman pengguna jalan sebagaimana dimaksud dalam Pasal 28 ayat (2) dipidana dengan pidana kurungan paling lama 1 (satu) bulan atau denda paling banyak Rp. 250.000,00 (dua ratus lima puluh ribu rupiah)".

Kedua pasal diatas adalah sanksi bagi orang yang melanggar atau mengambil hak pejalan kaki ditrotoar. Penerapan kedua pasal inilah yang dirasa kurang berjalan secara optimal. Masih banyak orang yang merasa tidak peduli dengan menggunakan fungsi trotoar tidak sesuai dengan peruntukannya seperti berdagang atau melintasi dengan kendaraan bermotor. Hal inilah yang disebut bahwa hukum tidak hanya bersifat formalitas saja, tetapi harus ada pengaplikasiannya secara nyata agar para pengguna trotoar yang dalam hal ini seorang penyandang disabilitas yang memang harus terpenuhi haknya sebagai warga negara Indonesia.

\section{Kesimpulan}

Karakteristik penggunaan trotoar sebagai fasilitas pejalan kaki termasuk penyandang disabilitas yang mencakup : Trotoar harus terdapat Guide Blok/ jalur pemandu berwarna kuning bagi tuna netra yang melintas, Terdapat Bollard untuk menghalangi kendaraan bermotor naik keatas trotoar, dan bentuk bollard tersebut tidak menyulitkan pengguna kursi roda melintas, Tedapat ramp untuk akses naik turun pengguna trotoar ke jalan raya, Permukaan trotoar yang kuat dan tidak licin sehingga tidak membahayakan pejalan kaki., Terdapat Pencahayaan yang cukup untuk faktor keamanan.

Trotoar berdasar ketentuan diatas maka dapat memfasilitasi para pejalan kaki dengan aman dan nyaman, dapat memfasilitasi pejalan kaki dari satu tempat ke tempat lain yang ditunjang dengan berbagai fasilitas. Perlindungan hukum preventif terhadap penyandang disabilitas yang melintas di Trotoar dilihat dari 
UU Lalu Lintas dan Angkutan Jalan adalah pejalan kaki berhak atas ketersediaan fasilitas pendukung berupa trotoar, tempat penyeberangan, dan fasilitas lain yang aman sesuai standar peraturan perundang-undangan. Subyek seorang pejalan kaki juga berlaku bagi seorang penyandang disabilitas. Seorang penyandang disabilitas juga mempunyai hak yang sama yaitu hak atas aksesibilitas menikmati sarana dan prasarana transportasi secara aman dan nyaman dan hal tersebut sudah disebutkan pada UU Penyandang Disabilitas. Selain perlindungan preventifjuga harus meliputi pelindungan represif,. Yaitu dimana seorang disablitas yang celaka dan dirugikan atas ketersediaan trotoar yang tidak sesuai standar, maka pemerintah menyediakan dan/atau memperbaiki pengaturan sarana dan prasarana lalu lintas yang menjadi penyebab kecelakaaan. Selain itu, pemerintah menyediakan alokasi dana untuk pencegahan dan penanganan kecelakaan lalu lintas.

\section{Daftar Bacaan}

\section{Buku}

Sakti Adji Adisasmita, Transportasi Komperehensif dan Multi Moda (Graha Ilmu 2014).

Muhammad Farouk, Praktik Penegakan Hukum Bidang lalu Lintas (Balai Pustaka 1999).

Muladi, Hak Asasi Manusai : Hakekat, Konsep dan Implikasinya dalam Perspektif Hukum dan Masyarakat (Refika Aditama 2005).

Akhmad Soleh, Aksesibiltas Penyandang Disabilitas terhadap Perguruan Tinggi : Studi Kasus di Empat Perguruan Tinggi di Yogyakarta (LKiS, 2016).

\section{Jurnal}

Aprilina Prawesti, 'Hak Penyandang Disabilitas Dalam Perspektif HAM Internasional dan HAM Nasional' (2017) 2 Jurnal Era Hukum.

Willy Putra, 'Pelaksanaan Perlindungan Hukum Terhadap Persamaan Hak Bagi Kelompok Penyandang Disabilitas Dalam Angkutan Penerbangan', Jurnal Hukum Adigama, (2018) 1 Jurnal Hukum Adigama.

Rina Saraswati, 'Kenyamanan Pejalan Kaki Terhadap Pemanfaatan Trotoar Di 
Jalan Brigjen Katamso Medan' (2017) 3 Jurnal Education Building.

\section{Laman}

Badan Pusat dan Penelitian Kesejahteraan Sosial Pusat Data dan Informasi Kesejahteraan Sosial Jakarta, www.perpustakaan.bapppenas.go.id.

Biro Komunikasi dan Informasi Publik,'Transportasi sebagai pendukung sasaran pembangunan nasional' (2017) www.dephub.go.id.

Sandro Gatra, 'Konvensi Hak Penyandang Disabilitas Diratifikasi' (2018) www. nasional.kompas.com.

Penyandang Disabilitas Kesulitan Lewati Totoar, (2018) www.pressreader.com/ indonesia/jawa-pos/20180310.

Banyak trotoar berubah menjadi tempat berjualan, pejalan kaki kehilangan haknya, (2016) www.surabaya.tribunnews.com. 